\title{
Effectiveness of Teaching the Pronunciation of Inflection Through Analytic-Linguistic Approach
}

\section{Lok Raj Sharma}

Associate Professor of English

Head of Faculty of Education

Makawanpur Multiple Campus, Hetauda, Nepal

Email: 1okraj043@gmail.com

Received: May 05, 2021; Revised \& Accepted: May 10, 2021; Published: June 30, 2021

(C) Copyright: Sharma (2021).

\section{ABSTRACT}

The principal objective of the research study is to examine the effectiveness of teaching the pronunciation of inflection in English words through the analytic-linguistic approach. The researcher followed a pre-experiment research design, especially one- group-pretest-posttestdesign, which included a pretest measure followed by a treatment and a posttest for a single group after the treatment or intervention. A set of fifty multiple choice test items was administered to the sample of 21 bachelor first year education students studying major English at Makawanpur Multiple Campus, Hetauda, Nepal in the Academic Year 2019-2020. The researcher adopted the census method also known as a statistical enumeration method wherein each and every student in the population was selected for eliciting the primary data. The result showed there was a statistically significant difference between the pretest mean score $(M=20.190, S D=14.169$ and $N=21)$ and the posttest mean score $(M=25.619, S D=14.844$ and $N=21)$ of the students. The statistics of $(d f)=20, p<.05$, the observed $t$-value $=4.38$ and the table $t$-value $=2.086$ at 0.05 significance level of the test showed that teaching the pronunciation of inflection through the analytic-linguistic approach was effective among the students at this campus. This study contributes to the existing body of the pronunciation of English words by highlighting that the same spelling functioning as the inflection of the English words has different pronunciation. It is shown through presentations.

Keywords: analytic-linguistic, consonant, inflection, pronunciation, teaching

\section{INTRODUCTION}

Teachers generally teach the pronunciation of root words in the course of teaching the pronunciation of English. The pronunciation of inflection is not often focused, but this article has focused on it and examined the effectiveness of teaching it through the analytic-linguistic approach. Teaching only the pronunciation of the roots is not enough. We need to teach the 
pronunciation of the affixes in the root words. Affixes are word attachments to a root or a stem of a word. These attachments are added to the front, middle or back of a word to change the meaning, parts of speech, gender or aspect of a word. There are three types of affixes: suffixes, prefixes and infixes. When an affix is added to the end of a word, it's called a suffix. When it's attached to the beginning of a word, it's called a prefix. When it's put in the middle of a word, it's called an infix. Infixes are much less common than suffixes and prefixes. Suffixes and prefixes can't normally be words themselves. To create a new word, they must be added to root or stem words. Suffixes can create new words by adding a letter or a group of letters to the end of a root word. Adding a suffix can change the spelling of a word. Suffixes can be class maintaining and class changing. The class maintaining suffixes do not change the part of speech as ' $s$ ' in the word 'cats', 'es' in the word 'goes' , 'er' in the word 'faster', 'ed' in the word 'worked'. Such class maintaining suffixes are called inflectional suffixes. It is a difficult task to deal with the suffixes. The same noun like 'sheep' can be singular and plural. Carstairs McCarthy (2002) mentions that the class of nouns which are not changed in the plural is analyzed as "carrying a zero suffix" (p. 35). The same verb like 'cut' can be the base form, the past form and the past participle form. To identify the singularity and plurality of the noun and the forms of the verb, we need to consider the syntactic context. The class changing suffixes change the part of speech of the words as 'ly' in the word 'slowly', 'er' in the word 'singer', 'ful' in the word 'harmful' etc. Such class changing suffixes are derivational suffixes. The prefix is a letter or a group of letters that is added to the beginning of a word as 're' in the word 'renew', 'dis' in the word 'dislike' and 'a' in the word 'atheist'. Infixes are added in the middle of a word as ' $s$ ' in the word 'passers-by', and ' $\mathrm{s}$ ' in the word 'mothers-in-law' etc.

The researcher's main concern was to discern the pronunciation of the inflectional suffixes in English words. He dealt with the pronunciation of just five inflectional suffixes: 's' 'es', 'ed' 'er' and 'ing' for his study. In the words in the native standard variety of English like Received Pronunciation (RP), there is not always corresponding relationship between spellings and their pronunciation. The same spellings have different pronunciation.

The spelling's' is pronounced / s / in the word 'bats', / z / in the word 'girls', /Iz / in the word 'buses' etc. Similarly, the spelling 'ed' is pronounced / d / in the word 'begged', / t / in the word 'laughed', /Id / in the word 'wanted' etc. Such suffixes are differently pronounced based on the final sounds of the words. This creates problem for the students to pronounce them correctly.

This article is based on the action research carried out in the classroom for solving the problem in pronouncing inflectional suffixes in English words. The fundamental objective of this study was to examine the effectiveness of teaching the pronunciation of inflection through the analytic-linguistic. Teaching the pronunciation of sounds by lecture method was found almost ineffective in the previous years; therefore the researcher was interested in finding out whether teaching pronunciation of inflection to the students through the analytic-linguistic approach was fruitful or just waste of time. He chose the bachelor first year education students whose major subject was English. They had to study pronunciation in their course of study entitled 
"Foundations of Language and Linguistics". The result showed the effectiveness of teaching the pronunciation of inflection through the analytic-linguistic approach. The researcher advises the teachers and the students not to skip any teaching items regarding the pronunciation though they might be tough for teaching and learning.

\section{SIGNIFICANCE OF THE STUDY}

Several research studies have been carried out in the field of teaching and learning activities, but the research study on the effectiveness of teaching the pronunciation of Inflection in the words of English of Received Pronunciation through an analytic- linguistic approach is new to the field of teaching. This research study is significant especially to all the teachers and students who are involved in teaching learning the pronunciation of English. It will also be fruitful to the persons who are interested in speaking in English. This study explores the practice of native speakers of English in speech that there's not always correlational relationship between the spellings and their pronunciation.

\section{OBJECTIVE OF THE STUDY}

The objective of the study was to examine the effectiveness of teaching the pronunciation of inflection through the analytic- linguistic approach.

\section{NULL HYPOTHESIS}

There is no statistically significant difference between the pretest mean score and the posttest mean score of the students.

\section{DELIMITATIONS OF THE STUDY}

The research was carried out under the following delimitations:

i. Only 21 bachelor first year education students majoring English were taken as the respondents.

ii. Only one campus was chosen as a study area.

iii. Pronunciation of speech sounds of English was taught to the students only for 25 days.

iv. Only fifty multiple choice test items regarding the pronunciation of inflection were administered to the students.

v. Only one- group- pretest- posttest pre-experimental research design was adopted to carry out research study.

\section{LITERATURE REVIEW}

The literature review includes the definitions and concepts of teaching, pronunciation, inflection, consonant sounds, vowel sounds, approaches to teaching pronunciation, and empirical outcomes of the previous studies.

\section{Teaching}

Teaching is a complex task. Teaching pronunciation or speech of sounds of a foreign language is even a more difficult and challenging task. Teaching is intended to bring a noticeable change at the previous level of knowledge of students in the related subject matter. Mangal and 
Mangal (2012) assert that "the teacher plays a very dominant and authoritarian role in teaching. It is he who decides about the methodology for the presentation of the subject material before the learner" (p. 156) . Teaching is a sort of giving input to the students for a notable output. We need to teach pronunciation of English to the students so that they can make their assertion intelligible. Zielinsky (2003) defines ineligibility as "the degree to which the speech produced by a speaker can be identified by a listener as the words the speaker intended to produce" (p. 1). Hockett (1972) holds the view that "our goal in teaching pronunciation is then the production of a sound system which does not interfere with communication, either from the speaker's or listener's point of view" (p. 62) . Dalton (2002) points out the reality and affirms that we are "comfortable teaching reading, writing, listening and to a degree, general oral skills, but when it comes to pronunciation we often lack the basic knowledge of articulatory phonetics to offer our students anything more than rudimentary and often unhelpful advice" (p. 72). The assertions made in this section reveal teaching as an intricate task and a teacher as a resourceful person who plays a crucial role in giving ample input to the students.

\section{Pronunciation}

Pronunciation is the production of speech that is a significant aspect in English language for communicating and contacting people by using words. Schmitt (2002) defines pronunciation as "a term used to capture all aspects of how we employ speech sounds for communication" ( $p$. 29). Each word has letters and each letter has a specific sound.

Boyer (2001) assumes that "each speaker has his/her own way in saying words in his/her normal speech" (p. 1).Gilakjani (2011) opines pronunciation as "the musical tones when the speech flows out smoothly, and if there is any weakness in the rhythm, misunderstanding will occur" (p. 74). Reid (2016) points out that "English pronunciation is very difficult for foreign learners and it is due to the fact that spelling and pronunciation are two different matters" (p. 19). It is very difficult for Asian students to learn the pronunciation of English, because they are not exposed to better English pronunciation in his earlier life. It is even more difficult for the Nepalese students, because family members do not speak English at home. Many English teachers do not have sound theoretical knowledge of pronunciation. It is true that intelligible pronunciation is must for communication. Teaching pronunciation helps students in a communicative affair through communicating meaning, function, mood and attitude in a proper way. It enhances their language skills and linguistic awareness. Wong (1993) asserts that the importance of pronunciation appears even more distinct when the connection between pronunciation and listening comprehension is taken into consideration.

Harmer (1990) affirms that the native speaker "unconsciously knows about stress and how it works. He knows which parts of individual words should be stressed and he knows how to put special meaning into the sentences by making different words more or less important" (p. 11).

Pronunciation of the English language is perceived as a difficult area by both teachers and students. Pronunciation has a long and distinguished history in second or foreign language 
teaching. Seidlhofer (2001) points out that teaching the pronunciation "stood at the very beginning of language teaching methodology as a principled, theoretically-founded discipline, originating with the late nineteenth-century Reform Movement" (p. 56). This Reform Movement brought the phoneticians from a number of European countries together, and this according to Collin and Mees (1999) and Howatt (2004) resulted in the establishment of pronunciation as a major concern of second language instruction lasting well into the second half of the twentieth century. Lee (2008) considers pronunciation as "an integral component of communication rather than an isolated drill" (p. 1). Morley (1994) highlights that "intelligible pronunciation is an essential component of communication competence" (p. 488). In the opinion of Otlowski (1998), "a learner's pronunciation in a foreign language needs to be taught in parallel to the communicative practices for the learner to be able to communicate effectively with native speakers" (p. 3). But it is impossible for the teachers to do so in all conditions.

Celce-Murcia, Brinton, Goodwin, and Griner (2010) by highlighting the importance of pronunciation stress that the speakers should "surpass the threshold level so that their pronunciation will not detract from their ability to communicate" (p. 9). Teaching pronunciation is an essential task for intelligible as well as good communication.

\section{Inflection}

Inflection involves the suffixes that do not change the part of speech. Crystal (2003) affirms that "inflectional affixes signal grammatical relationships, such as plural, past tense, and possession, and do not change the grammatical class of the stem to which they are attached" (p. 243). The inflectional suffixes are: 's', 'es', 'ed', 'er' and 'ing'.

$$
\begin{array}{ll}
\text { Cat }[\text { noun] }+\mathrm{s}=\text { Cats [noun] } & \text { Mango [noun] }+ \text { es }=\text { Mangoes [noun] } \\
\text { Read }[\text { verb] }+\mathrm{s}=\text { Reads [verb] } & \text { Go [verb] +es }=\text { Goes [verb] } \\
\text { Fast }[\text { adjective] }+ \text { er }=\text { Faster [adjective }] & \text { Tall [adjective] +est = Tallest [adjective] } \\
\text { Play }[\text { verb] }+ \text { ed }=\text { Played [verb] } & \text { Go [verb] }+ \text { ing }=\text { Going [verb] }
\end{array}
$$

\section{Consonant Sounds of English}

Standard British English (RP) language system involves twenty-four consonants and twenty vowel sounds. Crystal (2003) states that Consonants are "sounds made by a closure or narrowing in the vocal tract so that the airflow is either completely blocked, or so restricted that audible friction is produced" (p. 103). It means consonant sounds are produced when there is an obstruction of the airflow somewhere in the vocal tract. This obstruction is the point of contact between an active articulator and a passive articulator. In the view of Gimson (1990), speech is "a manifestation of language and spoken language is normally a continuum of sound" (p. 44). Connor (2000) opines that "consonants are generally made by a definite interference of the vocal organs with the air stream, and so are easier to describe and understand" (p. 24). Similar view is expressed by Verma and Krishnaswamy (1999) who take a consonant as "a sound characterized by constriction accompanied by some measure of friction or closure followed by release" (p. 35). The researcher has chosen the Standard British English, because the students have to study it in their course of study. Standard British English or Received Pronunciation is spoken by the 
people of the upper-middle and upper class throughout England. It is used in schools, press, radio and television programmes. Roach (1983) writes about the use of RP and mentions that "RP has always been chosen by British teachers to teach foreign learners. In addition, it has been mostly fully described and has been used as the basis for textbooks and pronouncing dictionaries" (p. 5).

Table 1

Inventory of Consonant Sounds of Standard British English with Different Spellings

\begin{tabular}{|c|c|c|c|c|c|}
\hline $\begin{array}{l}\text { S. } \\
\text { N. }\end{array}$ & Sound & Spellings & Initial Position & Medial Position & Final Position \\
\hline 1. & $/ \mathbf{P} /$ & $\mathrm{p}, \mathrm{pp}$ & pat, pun, pat & apple, apes & cap, up, rope \\
\hline 2. & $/ \mathbf{b} /$ & $\mathrm{b}, \mathrm{bb}$ & bat, but, boat & cabbage, rubs & rob, rub, sob \\
\hline 3. & $/ \mathbf{t} /$ & $\mathrm{t}, \mathrm{tt}$, th, ed & tune, Thomas, tie & cattle, cats, & but, hoped, laughed, rat \\
\hline 4. & $/ \mathbf{d} /$ & $\mathrm{d}, \mathrm{dd}$ & do, deed, dance & lads, bladder & lad, glad, shade, sad \\
\hline 5. & $/ \mathbf{k} /$ & $\begin{array}{l}\mathrm{k}, \mathrm{c}, \mathrm{ck}, \mathrm{ch}, \mathrm{q}, \\
\mathrm{cc},\end{array}$ & $\begin{array}{l}\text { kid, can, chorus, } \\
\text { quit }\end{array}$ & looks, locks, soccer & lake, luck, music, monarch \\
\hline 6. & $/ \mathbf{g} /$ & g, gg, gh & go, get, ghost & legs, baggage & leg, mug, log, hog \\
\hline 7. & / t t / & ch, tch, tu, & child, chop, chalk & $\begin{array}{l}\text { benches, butcher, } \\
\text { future }\end{array}$ & beach, match, bitch, catch \\
\hline 8. & $/ d \mathbf{d} /$ & $\begin{array}{l}\mathrm{j}, \quad \text { dge, } \mathrm{g}, \\
\mathrm{ge}, \mathrm{di}, \mathrm{de}\end{array}$ & jug, gin, gentle & $\begin{array}{l}\text { Ages, } \\
\text { grandeur }\end{array}$ & edge, large, age, sage \\
\hline 9. & $/ \mathbf{m} /$ & $\mathrm{m}, \mathrm{mm}$ & man, meet, map & summon, comes & sum, some, come \\
\hline 10. & $/ \mathbf{n} /$ & $\mathrm{n}, \mathrm{nn}, \mathrm{gn}$ & now, gnat, gnaw & hand, manner & can, ban, man, then \\
\hline 11. & $/ \mathbf{y} /$ & $\mathrm{n}, \mathrm{ng}$ & & rank, tank, kings & sing, ring, king, spring \\
\hline 12. & $/ \mathbf{f} /$ & f, ff, ph, gh & fan, phone, fat & suffer, lift & leaf, staff, rough, off \\
\hline 13. & $/ \mathbf{v} /$ & $\mathrm{v}, \mathrm{f}$ & van, vote, vain & leaves, lives & love, live, of, leave \\
\hline 14. & $/ \theta /$ & th & thin, thank, thumb & months, method & cloth, path, bath \\
\hline 15. & /ð/ & th & that, this, there & mother, father & bathe, clothe \\
\hline 16. & $/ \mathbf{s} /$ & $\mathrm{s}, \mathrm{ss}, \mathrm{sc}, \mathrm{c}$ & sun , scene, centre & fast, bosses, & bus, glass, place, race \\
\hline 17. & $\mid \mathbf{z} /$ & $\mathrm{z}, \mathrm{zZ}, \mathrm{s}, \mathrm{x}$ & zebra, zero, Xerox & puzzle, nuzzle & buzz, girls, topaz \\
\hline 18. & $/ \int /$ & $\begin{array}{l}\text { sh, s, ssio,tio, } \\
\text { tia, , ch }\end{array}$ & she, sure, chef & $\begin{array}{l}\text { worship, mission, } \\
\text { initial, motion }\end{array}$ & wash, bush, push, fish \\
\hline 19. & $/ 3 /$ & sio, sure, g & genre, jabot & division, measure & garage, beige, rouge \\
\hline 20. & $/ \mathrm{h} /$ & h, wh & home, how, who & behind, behave & \\
\hline 21. & $/ \mathbf{r} /$ & $\mathrm{r}, \mathrm{rr}, \mathrm{wr}$ & rat, write, right & spring, carry & \\
\hline 22. & $/ \mathbf{j} /$ & $y, u, e w, u e$ & yes, yak, yet & fuse, value, new & \\
\hline 23. & $/ \mathbf{w} /$ & $\mathrm{w}, \mathrm{wh}, \mathrm{qu}$ & was, what, why & swim, queen & \\
\hline 24. & /1/ & 1,11 & love, like, lie & girls, falls, pulse & tall, hall, real, fill \\
\hline
\end{tabular}




\section{Vowel Sounds of English}

Crystal (2003) holds his view that vowels are "sounds articulated without a complete closure in the mouth or a degree of narrowing which would produce audible friction" (p. 517). It means vowel sounds are produced with a friction of the airflow in the vocal tract. Therefore, they are voiced. Gimson (1990) assumes that speech is "a manifestation of language and spoken language is normally a continuum of sound" (p. 44). Connor (2000) views that "vowels are made by voiced air passing through different mouth shapes; the differences in the shape of the mouth are caused by different positions of the tongue and of the lips" (p. 79). Similar view is expressed by Verma and Krishnaswamy (1999) who consider a vowel as "a sound produced by the unobstructed passage of the airstream" (p. 34).

Standard British English (SBE) or Received Pronunciation is spoken by the people of the upper-middle and upper class throughout England. It is used in schools, press, radio and television programmes. This variety of English is used by most educated speakers. Giegerich (2009) has used a bit different vowel system of transcription that is shown in the following table.

\section{Table 2}

Inventory of Vowel Sounds of Standard British English with Different Spellings

\begin{tabular}{|c|c|c|}
\hline Usual System & Giegerich System (RP / SBE) & Spellings \\
\hline$/ \mathbf{I} /$ & $/ \mathbf{I} /$ & kid, pin, bill, red, ill etc. \\
\hline / i: / & $/ \mathbf{i} /$ & heat, lean, peel, bee, tea, eel etc. \\
\hline$/ \mathbf{e} /$ & $\mid \varepsilon /$ & bet, let, pen, end etc. \\
\hline$/ \mathfrak{a} /$ & $/ \mathbf{a} /$ & sat, that, pan, at etc. \\
\hline$/ \mathbf{\Lambda} /$ & / $\mathbf{\Lambda} /$ & cut, shut, but, nut etc. \\
\hline / ө / & /a / & common, bottom, ago, again etc. \\
\hline /3: / & $|3|$ & bird, first, curd etc. \\
\hline / a: / & / a / & fast, dart, bath etc. \\
\hline$/ \mathbf{p} /$ & $/ \mathbf{p} /$ & cot, dog, god etc. \\
\hline / $\mathbf{0 :} /$ & $|\boldsymbol{0}|$ & short, caught, bought etc. \\
\hline$/ 0 /$ & $/ \approx /$ & put, bull, full would, should etc. \\
\hline / u: / & $/ \mathbf{u} /$ & pool, food, moon, too, do etc. \\
\hline / eI / & $/ \mathbf{e} /$ & pane, late, make, shake, hate etc. \\
\hline / aI / & / aI / & line, mind, bite, buy, by, shy etc. \\
\hline / OI / & / OI / & noise, voice, coin etc. \\
\hline / $\partial \boldsymbol{~ / ~}$ & $/ 0 /$ & boat, load, pole etc. \\
\hline / av / & / av / & down, round, found, ground etc. \\
\hline / $\mathbf{1 0 ~ / ~}$ & / $\mathbf{1 \boldsymbol { \theta } /}$ & beard, fierce, weird etc. \\
\hline / eə / & / घə / & scarce, bairn, laird etc. \\
\hline
\end{tabular}




\begin{tabular}{|l|l|l|}
\hline$/$ ชə / & $/$ бə / & gourd, \\
\hline
\end{tabular}

\section{The Approach Employed for Teaching Pronunciation}

Celce-Murcia, Brinton and Goodwin (1996, as cited in Lee, 2008, p. 2) point out three main approaches to teaching pronunciation: intuitive-imitative approach, analytic-linguistic approach, and integrative approach.

The intuitive-imitative approach is used to teach pronunciation based on the learners' ability to listen and imitate the sounds and rhythm of the target language without giving any explicit information. According to this approach, it is assumed that there are always native listeners in the process.

The researcher adopted the analytic-linguistic approach to teach the pronunciation of inflection. The analytic-linguistic approach a phonetic alphabet, articulatory descriptions, charts of the vocal apparatus, contrastive information, and other aids to facilitate listening, imitation, and production of sounds. It explicitly informs the students, and focuses attention on the sounds and rhythms of the target language. This approach is used to complement rather than replacing the intuitive-imitative approach. This approach is based on analytical abilities of the students. In this approach, the teachers give the information regarding all the rules of the language i.e., phonetic symbols, stress pattern, articulation of the sounds, organs used to produce sounds, the rules for pronouncing the words in isolation and words with affixes etc. The students analyze this information and try to produce sounds accordingly. The integrative approach mainly focuses on suprasegmental features such as rhythm, intonation, stress, tempo and juncture. The learners need to practise such suprasegmentals in a discourse beyond the word level and phonemes.

Kelly (1969) mentions that the ways of teaching pronunciation fall into two groups: intuitive and analytical. The first group "depends on unaided imitation of models; the second reinforces this natural ability by explaining to the pupil the phonetic basis of what he / she is to do" (p. 61). Regarding the intuitive-imitative approach, Hismanoglu and Hismanoglu (2010) assume that "a student's ability to listen to and imitate the rhythms and sounds of the target language will give rise to the development of an acceptable threshold of pronunciation without the intervention of any explicit information" (p. 984). In the analytic-linguistic approach, explicit intervention of pronunciation pedagogy is emphasized. The learners are provided with explicit information on pronunciation using phonetic alphabet, articulatory descriptions, and vocal charts. Lee (2008) opines that the "explicit information can be presented in different interactive speech software and websites" (p. 1). Concerning the integrative approach, he affirms that "pronunciation is viewed as an integral component of communication, rather than an isolated drill and practice sub-skill" (p. 1). Roohani (2013) concerning the analytic--linguistic approach maintains that "different aspects of pronunciation such as place and manner of articulation, position of tongue and other aspects must be clarified by the teacher in the classroom" (p. 92). This researcher considers that the analytic-linguistic 
approach is a suitable one for teaching the pronunciation of speech sounds of English to the Nepalese students.

The Analytic-Linguistic Approach

Principally, the analytic- linguistic approach involves the following activities:

- Use of the phonetic alphabet

- Description on how to articulate words

- Use of Chart and other aids to supplement listening, imitation and production of sounds

- Focusing attention on the spellings and their corresponding sounds

- Providing the students with the contrastive information regarding the pronunciation

\section{Teaching Learning Activities}

Almost all the students make mistakes in pronouncing inflectional suffixes; therefore it is necessary to teach them the correct pronunciation. The researcher expects that the following presentations and conclusions or rules will be fruitful to English teachers and students. The researcher followed the following steps to teach the pronunciation of inflection:

Pre-Teaching Activities

- Motivating students to learn speech sounds of English

- Telling students on the necessity of correct pronunciation for communication

While Teaching Activities

- The researcher presented the phonetic alphabet ( Charts of sounds)

- The researcher pronounced each and every speech sound for the students

- The researcher presented several words which contained the intended sounds.

- The students were encouraged to listen to the tape record concerning the pronunciation of sounds prepared by the English native speaker / teacher.

- The students were introduced to the inflection with the pronunciation of each suffix.

Post Teaching Activities

- The researcher encouraged the students to pronounce each and every sound one by one.

- The students were asked to write several words which contained the particular sounds.

- The students were asked to point out the sounds of each suffix.

- The students were asked to draw the conclusion regarding the pronunciation of inflection as their home assignment.

\section{Presentation and Conclusion}

The researcher presented some words regarding the suffixes with their pronunciation, and drew the conclusions.

Pronunciation of Suffix ' $-s$ ' and '-es'

Presentation No. 1

caps /kæps/, beats / bi:ts /, books / buks/, laughs / la:fs/, months /msn $\theta \mathrm{s} /$, cat's / kæts/...

Conclusion 
$/ \mathrm{p} /, / \mathrm{t} /, / \mathrm{k} /, / \mathrm{f} /, / \theta /, / \mathrm{s} /, / \mathrm{f} /, / \mathrm{t} / /$ and $/ \mathrm{h} /$ are voiceless consonants. The suffix's' is pronounced /s/ after voiceless consonants other than $/ \mathrm{s} /, / \mathrm{f} /, / \mathrm{t} \mathrm{g} /$ and $/ \mathrm{h} /$.

\section{Presentation No. 2}

verbs /vs:bz/ , builds /bildz/, bags /bægz/, lives /rvz/, rams $/ \mathrm{ræmz} /$, pens /penz/

kings $/ \mathrm{kmz} /$, balls / bo:lz/, clothes /kəuð̃ /, man's /mænz/ ...

Conclusion

/b/, /d/, /g/, /dz/, /m/, /n/, /y/,/v/,/ð/,/z/,/z/,/r/, /j/, /w/ and /1/ are voiced consonants. The suffix's' is pronounced /z / after voiced consonants other than /dz/, /, /z/, /z/, /r/, /j/, and /w/. We should tell our students that sounds $/ \mathrm{r} /, / \mathrm{j} /$, and $/ \mathrm{w} /$ do not occur at the end of the words, but letters may occur and they work as vowel sounds.

\section{Presentation No. 3}

cows $/ \mathrm{kauz} /$, buys $/ \mathrm{bauz} /$, plays $/ \mathrm{pleız} /$, ears $/ \mathrm{raz} /$, boys $/ \mathrm{bouz} /$, shows $/$ jouz/, bees $/ \mathrm{bi:z} /$

$\operatorname{cars} / \mathrm{ka:z} /$, cow's $/ \mathrm{kauz} /$, goes $/$ gauz/...

\section{Conclusion}

The suffix ' $s$ ' is pronounced / $\mathrm{z} /$ after the vowels that are also voiced sounds. The spellings ' $\mathrm{w}$ ' and ' $y$ ' at the end of the words do not work as the consonant sounds. They work as vowel sounds. The spelling ' $r$ ' at the end of word in isolation remains silent.

\section{Presentation No. 4}

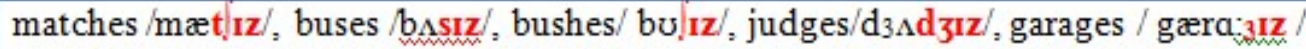

buzzes $/ \mathrm{b}_{\mathrm{Az}} \mathrm{IZ} / \ldots$

\section{Conclusion}

The spellings 'es' is pronounced /Iz/ after the consonant sounds /dz/, /z/,/z/, /s/, / $/$ and / $\mathrm{t} f$.

Pronunciation of Suffix '-ed'

\section{Presentation No. 1}

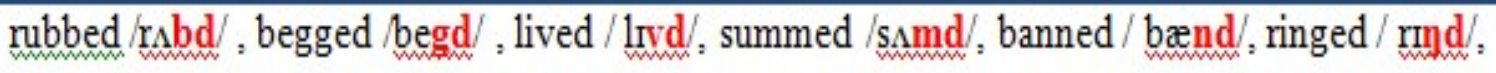 called $/ \mathrm{ko} \cdot \mathrm{ld} /$, judged $\mathrm{d}_{3 \Lambda \mathrm{d}} \mathrm{d} /$, breezed / bri:zd/, garaged / gæra: $3 \mathrm{~d} / \ldots$}

\section{Conclusion}

/b/, /d/, /g/, /dz/, /m/, /n/,/y/, /v/, /ð/,/z/, /z/, /r/, /j/, /w/ and /1/.are voiced consonants. The suffix 'ed' is pronounced $/ \mathrm{d} /$ after voiced consonants other than $/ \mathrm{d} /$.

\section{Presentation No. 2}


rowed $/ \mathrm{raud} /$ (noise), lied / bard/, played /plerd/, sawed /so:d/(cut),employed / mplord/ showed $/$ joud $/ \ldots$

Conclusion

The spelling 'ed' is pronounced /d/ after vowel sounds. It is to remember that the spellings ' $w$ ' and ' $y$ ' at the end of the words remain silent or work as vowel sounds.

Presentation No. 3

helped /helpt/, looked /ukt/, laughed /a:ft/, missed $/ \mathrm{mIst} /$, pushed $/ \mathrm{pu} / \mathrm{t} /$, watched $/ \mathrm{w} \cdot \mathrm{t} \cdot \mathrm{t} / \ldots$

Conclusion

$/ \mathrm{t} /, / \mathrm{k} /, / \mathrm{f} /, / \theta /, / \mathrm{s} /, / \mathrm{J} /, / \mathrm{t} /$ and $/ \mathrm{h} /$ are voiceless consonants. The suffix 'ed' is pronounced $/ \mathrm{t} /$ after voiceless consonants other than $/ \mathrm{t} /$.

Presentation No. 4

wanted $/$ wontıd/, fainted $/$ femtıd/, needed $/$ ni:d Id/, heeded $/$ hi:drd/ $\ldots$

Conclusion

The spelling 'ed' is pronounced /Id / after /d/ and /t/.

Pronunciation of suffixes '-er', '-est', and '-ing'

Presentation No.1

taller /to:lə(r) /, tallest /to:lıst/, selling /selın / ...

Conclusion

The pronunciation of suffix 'er' is / $\partial(\mathrm{r})$ /, that of 'est' is /Ist / and that of 'ing' is /In / in each and every word of English. The suffixes 's', 'es' and 'ed' are realized by different sounds in different words which end in different consonant sounds, but other suffixes like 'er', 'est', , 'ing' 'ly' and so on have the same pronunciation in different words as / $\partial(\mathrm{r})$ / in singer / player, / ist / in tallest / youngest, /in / in reading / sleeping, / 1 / in badly/ slowly, / fl / in harmful/ careful, / nəs / in hardness/ badness and so on.

\section{METHOD AND MATERIALS}

This article is based on the quantitative research method that is an overall plan for collecting, analyzing and interpreting data. 


\section{Research Design}

The researcher followed the one- group- pretest- posttest pre-experimental research design to carry out this research study. Population

Twenty-one bachelor first year education students studying English as a major subject at Makawanpur Multiple Campus, Hetauda, formed the population of the study.

\section{Sample Size and Sampling Technique}

The sample size of the study consisted of 21 bachelor first year education students majoring English in the academic year 2019-2020. The researcher followed the census method also known as a statistical enumeration method wherein each and every student in the population was selected for eliciting the primary data. Census was used because the intended population was low. Kothari (2011) defines a census inquiry as "a complete enumeration of all items in the population" (p. 55). The sample size of the research study consisted of boys and girls.

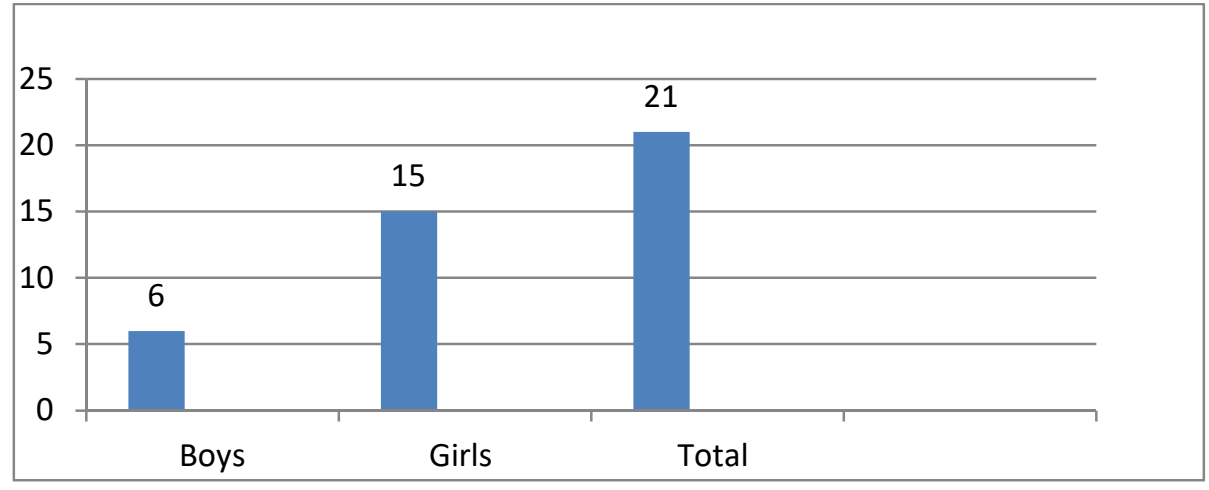

Figure 1. Number of participants by sex

This figures shows that the number of girls was higher than the number of boys in the study.

\section{Nature and Sources of Data}

The researcher collected ratio scale data from fifty multiple choice pretest and posttest test items based on the pronunciation of inflection. The primary data were collected through the pretest and the posttest scores of the students. The researcher made use of different books, journal articles, theses, and other related materials as the secondary sources of data.

\section{Validity of Instruments}

To assess the validity of the instruments, the researcher studied the objective questions asked in the final exams conducted by this Campus and Tribhuvan University, Nepal in 10 different years. He showed the objective questions regarding the pronunciation to the lecturers who teach phonetics and phonology at the neighboring campuses and received suggestions for improving the questions. He also went through some journal articles that dealt with teaching the pronunciation of English.

\section{Reliability of Instrument}

The researcher used the Split-Half model of reliability to check the reliability of the instruments. The reliability of the instruments based on the pretest scores of the students was 
.866 and that of the instruments on the posttest score was .798. The data showed us that the instruments were very reliable in measuring students' achievement in learning the pronunciation of inflection.

\section{Variables in the Study}

In this pre-experimental research design, the analytic-linguistic approach used to teach the pronunciation of inflection was the independent treatment variable, and the pretest and the posttest scores that indicated the students' achievement or learning were dependent variable. The sex of the students was a demographic variable.

\section{ANALYSIS AND INTERPRETATION OF DATA}

All the data were analyzed by using Statistical Package for Social Sciences (SPSS) 20 version. The researcher used both descriptive statistics such means and standard deviation to analyze the pretest and posttest scores, and the inferential statistical tests to examine the hypothesis in the study. The researcher used the paired samples t- test to assess the null hypothesis test at the significance level of 0.05 . The researcher made use of G Power 3.1 Software to measure the power of the hypothesis test.

\section{Paired Samples T-Test}

The Paired-Samples t- Test was employed to compare the means of two variables for a single group. In this research study, the total posttest score and the total pretest score were two dependent variables whose means were to be compared for analysis.

\section{Table 2}

Significance of Difference Between the Total Posttest and The Total Pretest Mean Scores of the Students.

\section{Paired Samples T- Test}

Paired Variables: Total posttest score and total pretest score Group: Single

\begin{tabular}{|c|c|c|c|c|c|c|c|c|}
\hline Score & Mean & $\mathbf{N}$ & $\begin{array}{l}\text { Std. } \\
\text { Deviation }\end{array}$ & $\begin{array}{l}\text { Std } \\
\text { Error } \\
\text { Mean }\end{array}$ & $\begin{array}{l}\text { Table } \\
\text { Value }\end{array}$ & $\begin{array}{l}\text { Observed } \\
\text { Value }\end{array}$ & Df & Sig. (2-tailed) \\
\hline $\begin{array}{l}\text { Total } \\
\text { Posttest }\end{array}$ & 25.619 & 21 & 14.844 & 3.239 & \multirow[t]{2}{*}{2.086} & \multirow[t]{2}{*}{4.380} & \multirow[t]{2}{*}{20} & \multirow[t]{2}{*}{.000} \\
\hline $\begin{array}{l}\text { Total } \\
\text { Pretest }\end{array}$ & 20.190 & 21 & 14.169 & 3.091 & & & & \\
\hline
\end{tabular}

The table of paired samples t- test, which employed the total posttest score and the total pretest score as paired variables, indicated that there was a remarkable difference between the 
pretest mean score $(\mathrm{M}=20.190, \mathrm{SD}=14.168$ and $\mathrm{N}=21)$ and the posttest mean score $(\mathrm{M}=$ $25.619, \mathrm{SD}=14.844$ and $\mathrm{N}=21$ ) of the students.

The table further shows that the probability figure marked as Sig (2-tailed) or $\mathrm{p}$ - value in the table was .000 which was smaller than 0.05. Similarly, the observed value (4.380) was greater than the table value (2.086). Therefore, the null hypotheses were rejected. It implies that there was a statistically significant difference between the pretest mean score and the posttest mean score of the students. The difference was caused because of teaching through the analyticlinguistic approach. It obviously indicates the effectiveness of teaching,

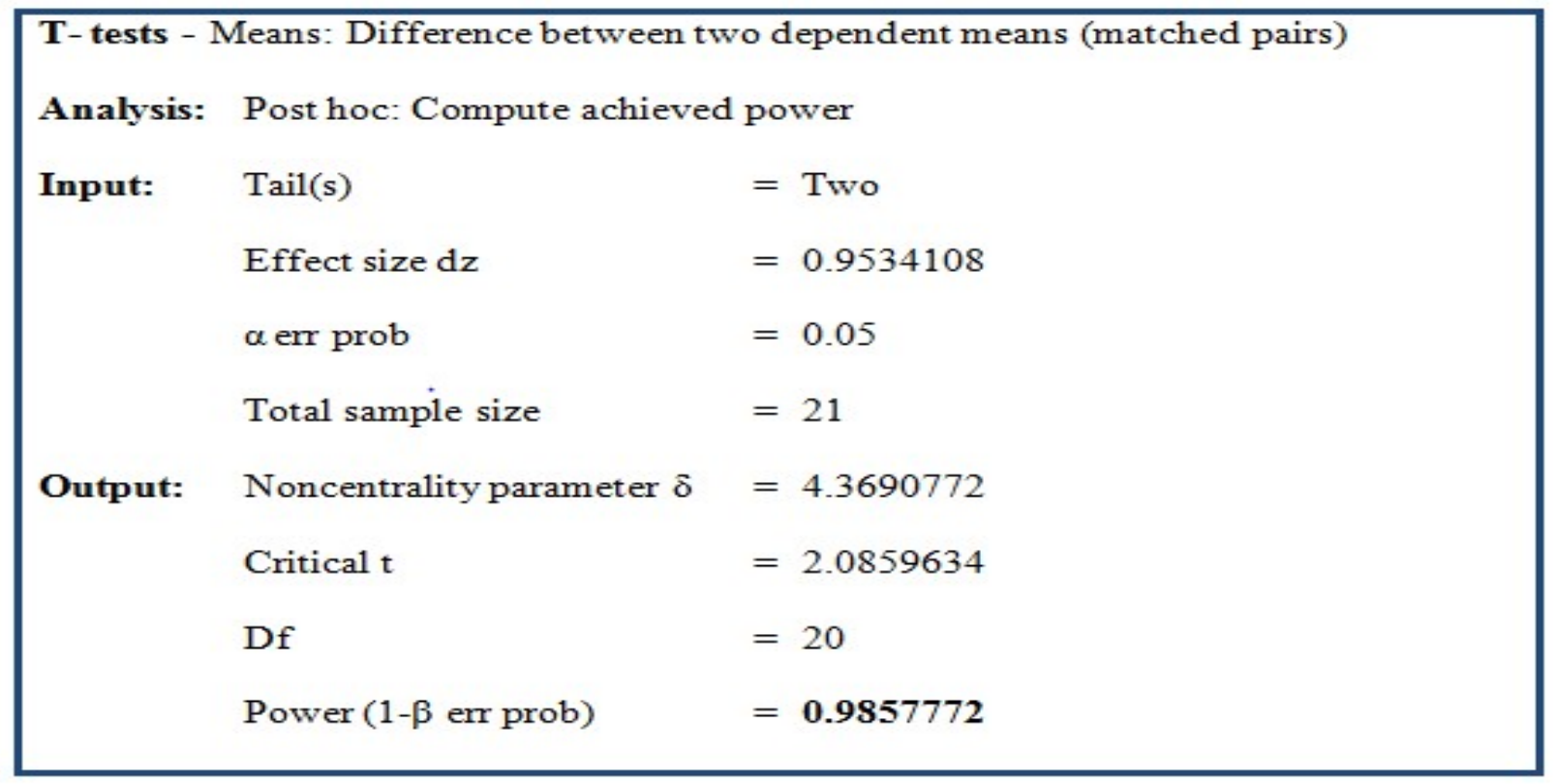

Figure 2. Power of hypothesis test

The researcher made use of G Power 3.1 Software to measure the power of the hypothesis test. The power of the hypothesis test (1- $\beta$ err prob) involving the pretest mean score and the posttest mean score of the students was 0.985 . It indicates that the test was considered to be working perfectly well. It implies that there was $98.5 \%$ chance of correctly rejecting the null hypothesis (H0) and accepting the alternative hypothesis (H1) with 21 students. The following figure shows the power of hypothesis test with different sample sizes. 


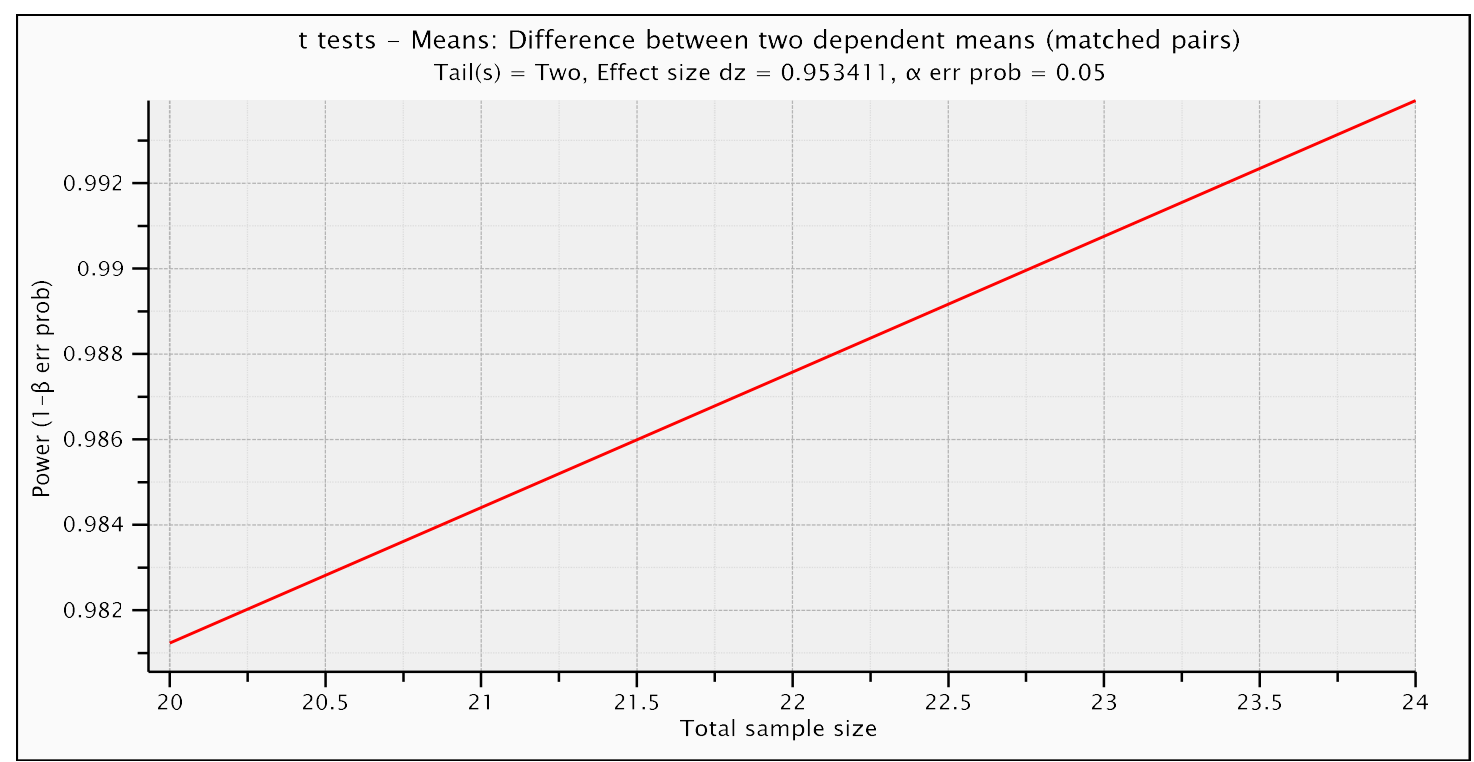

Figure 3. Power of hypothesis test with different sample sizes

This figure shows that the power of hypothesis test increases with an increase of a sample size. The sample size in this research study was low, because the number of students studying major English was low.

\section{RESULTS AND DISCUSSION}

The descriptive statistic confirms that the difference between the pretest mean score $(\mathrm{M}=$ $20.190)$ and the posttest mean score $(M=25.619)$ of students was significantly different. The inferential statistic which involved paired sample t-test indicates that probability figure marked as Sig (2-tailed) or p was .000, the observed t- value was 4.380) and the table t- value was 2.086 . These data show the rejection of the null hypothesis and further justify that there was a statistically significant difference between the pretest mean score and the posttest mean score of the students. The difference between these two mean scores occurred due to the effect of the analytic-linguistic teaching approach as a treatment or intervention. The power of hypothesis test (1- $\beta$ err prob) was .985 that shows $98.5 \%$ chance of correctly rejecting the null hypothesis with 21 students who were participants in the study.

Wei (2006) started his research due to the problems in teaching pronunciation in the Asian EFL context, and provided that computer-assisted language learning and self monitoring as source of strategies and techniques that teachers can use in their classrooms used in teaching intonation, stress and rhythm, vowels and consonants. Demirezen (2010) put forward a new model called the audio articulation model with the intention of correcting fossilized errors and expanding the horizons of professional pronunciation teaching. A study carried out by Atli and Bergil (2012) taking pretest and post of questionnaire administered to 2o ELT students for collecting data showed the effectiveness of the pronunciation instruction on students' overall speaking ability. 
Roohani (2013) in her study found that the intuitive-imitation approach was more effective for the younger participants, whereas the analytic-linguistic approach was more effective for the older ones. Hashemian and Fadaei (2011) using 40 Iranian foreign learners carried out a study to examine the effectiveness of intuitive-imitative and analytic-linguistic approaches on teaching vowels and diphthongs concluded that language learners who were taught through the intuitive-imitative approach contributed to a better pronunciation regarding diphthongs. However, the research study carried out by Hismanoglu and Hismanoglu (2010) with the 103 EFL teachers in English Preparatory Schools revealed the teachers' preference for using traditional techniques such as dictation, reading aloud and dialogues rather than using modern techniques like analytic-linguistic approach. The present study shows that the analyticlinguistic approach to teaching the pronunciation of inflection was effective.

\section{CONCLUSION AND RECOMMENDATION}

Teaching the pronunciation of inflectional suffixes in English words through the analyticlinguistic teaching approach was effective though it was too tough and challenging for a Nepalese English teacher to teach Nepalese students who were poor in English. The result suggests that the analytic-linguistic approach to teaching the pronunciation of inflectional suffixes is an effective, and it may be effective in teaching the pronunciation of English on the whole. This study is significant, because it contributes the correct pronunciation of inflectional suffixes to the pronunciation of English words and helps the students maintain intelligible pronunciation in the area of the pronunciation of English. The concerned teachers are recommended to use the analytic-linguistic teaching approach in teaching the pronunciation of speech sounds. Theoretically, it is impossible to teach all the aspects of segmental and suprasegmental features of a language by using a single teaching approach to all the students, and practically, it is impossible to use several approaches to teach particular sounds within a given period of time in the classroom, therefore this researcher recommends the future researchers to carry out several researches in the field of teaching pronunciation to come up with a proper approach of teaching in the days to come.

\section{REFERENCES}

Atli, I., \& Bergil A, S. (2012). The effect of pronunciation instruction on students' overall speaking skills. Procedia-Social and Behavioral Sciences, 46, 3665-3671.

Boyer, S. (2001). Understanding English pronunciation: An integrated practice course. Australia: Boyer Educational Resources.

Carstairs-McCarthy, A. (2002). An introduction to English morphology: Words and their structures. Edinburgh: Edinburgh University Press.

Celce-Murcia, M., Brinton, D. M., Goodwin, J. M., \& Griner, B. (2010). Teaching pronunciation: A course book and reference guide. Cambridge: Cambridge University Press. 
Connor, J. (2000). Better English pronunciation . Delhi: Cambridge University Press.

Crystal, D. (2003). A dictionary of linguistics and phonetics . Oxford: Blackwell Publishing.

Dalton, D. (2002). Some techniques for teaching pronunciation. Retrieved from Retrieved July 21, 2020 from: http://iteslj.org/techniques/ Dalton- pronunciation.html

Demirezen, M. (2010). The principles and applications of the audio-lingual pronunciation rehabilitation model in foreign language teacher education. Journal of Language and Linguistic Studies, 6(2), 127-148.

Giegerich, H. (2009). English phonology: An introduction. Cambridge: Cambridge University Press. Cambridge: Cambridge University Press.

Gilakjani, A. (2011). Why Pronunciation so difficult to learn? English Language Teaching, 4(3), 74. Retrieved from Retrieved from VU E-Journals Library database.

Gimson, A. (1990). An introduction to the pronunciation of English (ELBS 4th edition). Revised by Susan Ramsaran . London: English Language Book Society.

Harmer, J. (1990). The practice of English language teaching. Harlow: Longman.

Hashemian, M., \& Fadaei, B. (2011). A comparative study of intuitive-imitative and analyticlinguistic approaches towards teaching English vowels to L2 learners. Journal of Language Teaching and Research, 2(5), 969-976.

Hismanoglu, M., \& Hismanoglu, S. (2010). Language teachers' preferences of pronunciation teaching techniques: Traditional or modern? Procedia-Social and Behavioral Sciences, 2(2), 983-989.

Hockett, C. F. (1972). Learning pronunciation. In K. Croft (Ed.), Readings on English as a second language (p. 68). Cambridge, MA: Winthrop Publishers.

Kelly, L. G. (1969). 25 centuries of language teaching. Rowley, MA: Newbury House.

Kothari, C. (2011). Research methodology: methods and techniques. New Delhi: New Age International (P) Limited.

Lee, S. (2008). Teaching pronunciation of English using computer assisted learning software: An action research study in an institute of technology in Taiwan. Doctoral dissertation, Australian Catholic University.

Mangal, S., \& Mangal, U. (2012). Essentials of educational technology. New Delhi: PHI Learning Private Limited. New Delhi: PHI Learning Private Limited.

Morley, J. (1994). A multidimensional curriculum design for speech pronunciation instruction. . (P. p.-9. J. Morley, Ed.) Illinois: Pentagraph Print.

Otlowski, M. (1998). Pronunciation: What are the Expectations? The Internet TESL Journal, 4(1), 1-3. Retrieved from <http: // itesl.org / Articles / Otlowski -Pronunciation.html>

Reid, E. (2016). Teaching English pronunciation to different age groups. Retrieved from Retrieved from https://www.researchgate.net/publication/312495294

Roach, P. (1983). English phonetics and phonology: A practical course. Cambridge: Cambridge University Press. Cambridge: Cambridge University Press. 
Roohani, A. (2013). A comparative study of intuitive-imitative and analytic-linguistic approaches to teaching pronunciation: Does age play a role? The Asian EFL Journal Quarterly, 15(1), 87-127.

Schmitt, N. (. (2002). An introduction to applied linguistics. London: Oxford University Press.

Seidlhofer, B. (2001). Pronunciation. (R. C. (pp56-65)., Ed.) Cambridge: Cambridge University Press.

Verma, S., \& Krishnaswamy, N. (1999). Modern linguistics. New Delhi: Oxford University Press. New Delhi: Oxford University Press.

Wei, M. (2006). A literature review on strategies for teaching pronunciation. ERIC Document Reproduction Service No. ED491566.

Wong, R. (1993). Teaching EFL pronunciation: Why, what and how? Retrieved from Retrieved March 1, 2021 from http://www.creativeproed.com/teaching/teaching-eflpronunciationwhy-What-and-how/index.html.

Zielinski, B. (2003). Intelligibility in speakers of English as a second language. Retrieved fro m Retrieved July 21, 2020, from http://www.englishaustralia.com.au/ea_conference03/proceedings/pdf/040F_Ziekinskipp df 